Cite this: J. Anal. At. Spectrom., 2014, 29, 903

Received 26th July 2013

Accepted 13th February 2014

DOI: 10.1039/c3ja50241d

www.rsc.org/jaas

\section{Matrix effects during laser ablation MC ICP-MS analysis of boron isotopes in tourmaline}

\begin{abstract}
Jitka Míková, ${ }^{\star a b}$ Jan Košler ${ }^{a}$ and Michael Wiedenbeck ${ }^{c}$
Laser ablation multi-collector inductively coupled plasma mass spectrometry (LA MC ICP-MS) and secondary ion mass spectrometry (SIMS) were used to determine the boron isotopic compositions of several natural tourmaline group minerals (elbaite, schorl and dravite). This study reports on the effects of instrument parameters of LA MC ICP-MS and the composition of sample matrix on data accuracy, reproducibility and repeatability. We demonstrate that the tourmaline matrix has a significant effect on the obtained $\delta^{11} \mathrm{~B}$ values and impacts on data accuracy, with a bias of up to $c a .2 .5 \%$ if a non matrixmatched reference material is used to calibrate the measurements. In the case of a matrix-matched calibration, the boron isotopic data obtained by LA MC ICP-MS are comparable to the reference TIMS values, with typical repeatability for $\delta^{11} \mathrm{~B}$ results between 0.2 and $0.5 \%$ (1s). This is somewhat better compared to the repeatability of $0.8-1.3 \%$ (1s) for small format single collector SIMS.
\end{abstract}

\section{Introduction}

The isotopic composition of boron with its two stable isotopes, ${ }^{10} \mathrm{~B}$ and ${ }^{11} \mathrm{~B}$, has proven to be a powerful tool for studying geochemical processes in natural systems. Large fractionation of B isotopes in nature (up to $90 \%$, ref. 1 ) has been linked to its geochemical characteristics, such as high solubility and mobility in aqueous solutions and incompatibility in most magmatic systems. Boron isotopes often record transfer and mixing processes in the Earth as well as planetary systems. The utility of boron isotopes in geochemical studies was reviewed by Palmer and Swithart ${ }^{2}$ and Leeman and Sisson. ${ }^{3}$

Boron isotope ratios are expressed in $\delta^{11} \mathrm{~B}$ notation $\left(\delta^{11} \mathrm{~B} \%\right.$ $\left.\left[\left({ }^{11} \mathrm{~B} /{ }^{10} \mathrm{~B}\right)_{\text {sample }} /\left(\left({ }^{11} \mathrm{~B} /{ }^{10} \mathrm{~B}\right)_{\text {reference }}-1\right)\right] \times 1000\right)$ where the reference ${ }^{11} \mathrm{~B} /{ }^{10} \mathrm{~B}$ ratio usually corresponds to the composition of the NIST SRM 951 boric acid reference material, which has a certified ${ }^{11} \mathrm{~B} /{ }^{10} \mathrm{~B}$ value of $4.04362 \pm 0.00137 .{ }^{4}$ Tonarini et al. ${ }^{5}$ have reviewed various techniques used to measure the isotopic composition of B in natural samples, including positive thermal ionisation mass spectrometry (PTIMS), ${ }^{6-8}$ negative ion thermal ionisation mass spectrometry (NTIMS), ${ }^{\mathbf{9 , 1 0}}$ inductively coupled plasma mass spectrometry (ICP-MS), ${ }^{\mathbf{1 1}}$ multiple-collector ICPMS (MC ICP-MS), ${ }^{12}$ secondary ion mass spectrometry (SIMS or ion probe) $)^{\mathbf{1 3 , 1 4}}$ and laser ablation ICP-MS (LA ICP-MS). ${ }^{15,16}$ The analytical uncertainties currently reported for boron isotopic

${ }^{a}$ Centre for Geobiology and Department of Earth Science, University of Bergen, Allegaten 41, Bergen, N-5007, Norway

${ }^{b}$ Czech Geological Survey, Klárov 3, Prague 1, CZ-118 21, Czech Republic. E-mail:jitka. mikova@geology.cz

'Helmholtz Centre Potsdam, GFZ German Research Centre for Geosciences, Telegrafenberg, 14473 Potsdam, Germany analysis of geological materials vary from 0.2 to $4 \%$. Several analytical technique and inter-laboratory comparisons have been carried out to identify the potential source of analytical uncertainties. Tonarini et al. and Gonfiantini et al. ${ }^{\mathbf{8 1 7}}$ showed a significant spread in results and poor agreement between different laboratories. The source of the observed variations in their study was likely related to the specific techniques used for boron extraction and purification or to differences in analytical procedures. In order to further improve data inter-comparison between laboratories, Aggarwal et al. ${ }^{18}$ carried out a round robin study based on the analysis of synthetic solutions that contained boron. Despite large inter-laboratory differences, this study suggested no systematic bias induced by different analytical techniques. ${ }^{18}$ With the exceptions of SIMS and LA ICP-MS, the isotopic analysis of boron typically requires chemical separation prior to the mass spectrometric measurement. The separation of boron from the sample matrix must be performed with great care to prevent contamination of samples and fractionation of boron isotopes. The latter is a major risk due to the high volatility of boron and high relative mass difference between ${ }^{10} \mathrm{~B}$ and ${ }^{11} \mathrm{~B},{ }^{19-22}$ and means that solutionbased techniques can be difficult to implement. In addition, any application of boron isotope geochemistry (e.g., investigation of mineral zoning patterns or melt inclusions) requires that the analysis be performed in situ and with spatial resolution on the order of tens of micrometers, such as provided by SIMS and LA MC ICP-MS. The reported analytical uncertainties for determination of $\delta^{11} \mathrm{~B}$ by LA MC ICP-MS in geological materials with boron concentrations ranging from tens to tens of thousands $\mu \mathrm{g} \mathrm{g}^{-1}$ are better than $\pm 2 \%{ }^{16}{ }^{16}$ Both in situ techniques are, however, prone to matrix effects; accordingly, a matrix-matched calibration is often required to correct for instrumental mass 
bias. Boron isotope determinations conducted in situ by LA MC ICP-MS ${ }^{15,16}$ have so far only been applied to natural and synthetic glasses, and further work is required in order to properly assess the possible matrix effects during the analysis of natural rocks and minerals. ${ }^{15}$

Tourmaline represents the principal mineralogical sink for B in a broad spectrum of silicate systems. The complex and variable composition of the tourmaline mineral group in nature $(\mathrm{Na}, \mathrm{Ca})(\mathrm{Mg}, \mathrm{Fe}, \mathrm{Mn}, \mathrm{Li}, \mathrm{Al})_{3}\left(\mathrm{Al}, \mathrm{Mg}, \mathrm{Fe}^{3+}\right)_{6}\left(\mathrm{Si}_{6} \mathrm{O}_{18}\right)\left(\mathrm{BO}_{3}\right)_{3}(\mathrm{O}$, $\mathrm{OH})_{3}(\mathrm{OH}, \mathrm{F})$ provides a record of differentiation mechanisms and evolution of magmatic hydrothermal fluids in many granites and pegmatites. ${ }^{23,24}$ The crystallochemical properties of tourmaline have been shown to reflect the environment in which it was formed [e.g., ref. 25 and references therein]. Boron isotope studies of tourmaline have mostly provided insights into the sources of boron, but B isotopes have also been used to constrain tectonic settings, temperature of tourmaline formation, fluid-rock interaction and metamorphic processes [ref. 2 and references therein, ref. 26 and 27]. While tourmalines are often compositionally complex and are difficult to digest chemically without the loss of boron or fractionation of its isotopes, LA ICP-MS may overcome these difficulties and can be a method of choice for boron isotopic studies.

This study provides a detailed description of the analysis of tourmaline by LA MC ICP-MS and presents a comparison of this method with the more commonly used in situ isotopic analysis of tourmalines by SIMS. The primary objective of this study is to evaluate the possible matrix effects that might impact the LA MC ICP-MS analysis of tourmalines.

\section{Samples and experimental}

\section{Tourmaline samples}

We have analysed a suite of tourmaline samples of different chemical compositions that have been well characterized by previous studies (Table 1). Their B isotopic composition varies from isotopically light $\left(\delta^{11} \mathrm{~B}=-18.98 \%\right.$ o $)$ to isotopically heavy $\left(\delta^{11} \mathrm{~B}=10.63 \%\right.$ ). Three of the samples (98144 elbaite, 108796 dravite and 112566 schorl) were characterised by Dyar et al. ${ }^{28}$ and Leeman and Tonarini ${ }^{29}$ specifically for the use as reference

Table 1 Boron contents and $\delta^{11} B$ values of the samples analysed in this study

\begin{tabular}{|c|c|c|c|c|c|}
\hline Sample & $\mathrm{B}(\mathrm{ppm})$ & Analytical technique & $\delta^{11} \mathrm{~B}$ & $1 s$ & Reference \\
\hline $\begin{array}{l}98144 \\
\text { elbaite }\end{array}$ & 31402 & $\begin{array}{l}\text { TIMS, SIMS } \\
\text { (concentration) }\end{array}$ & -10.40 & 0.20 & 28 and 29 \\
\hline $\begin{array}{l}108796 \\
\text { dravite }\end{array}$ & 31091 & $\begin{array}{l}\text { TIMS, SIMS } \\
\text { (concentration) }\end{array}$ & -6.60 & 0.10 & 28 and 29 \\
\hline $\begin{array}{l}112566 \\
\text { schorl }\end{array}$ & 31153 & $\begin{array}{l}\text { TIMS, SIMS } \\
\text { (concentration) }\end{array}$ & -12.50 & 0.05 & 28 and 29 \\
\hline B4 (schorl) & 28700 & $\begin{array}{l}\text { TIMS + } \\
\text { isotope dilution }\end{array}$ & -8.85 & 0.17 & 8 \\
\hline EZ-272 & & TIMS & -14.17 & 0.23 & 30 \\
\hline JS-82N-1 & & TIMS & -1.63 & 0.36 & 30 \\
\hline JS-82A-1A & & TIMS & -18.98 & 0.38 & 30 \\
\hline EB-67-90 & & TIMS & 10.47 & 0.36 & 30 \\
\hline
\end{tabular}

materials. The sample B4 was used for an inter-laboratory comparison study. ${ }^{\mathbf{8 , 1 7}}$ These four tourmalines represent some of the very best characterised materials for in situ analysis of boron isotopes that are presently available to the geoanalytical community. Four additional samples (EZ-272, JS-82N-1, JS-82A1A, and EB-67-90) are from the boron isotopic study by Palmer and Slack. ${ }^{30}$ Isotopic heterogeneity of the individual samples is reflected by the standard deviation of their B isotopic composition ( $c f$. Table 1) and it grossly coincides with the reported repeatability of the in situ techniques used for their characterization. ${ }^{\mathbf{8 , 1 6 , 2 8 - 3 0}}$

All samples were mounted in epoxy resin and polished to obtain flat and smooth surfaces suitable for electron probe micro-analysis (EPMA), SIMS, and LA MC ICP-MS analysis. Tourmaline grains were split into two sample mounts. The mount S1 contained the samples 98144 elbaite, 108796 dravite, 112566 schorl and B4; and the mount S2 contained the Palmer and Slack tourmalines along with 98144 elbaite and 108796 dravite. As the ablation cell was capable of holding only one sample mount at a time, and our reference materials were mounted together with the samples, data obtained from each sample mount were treated separately to avoid any potential effect resulting from variations in analytical conditions and changing sample mounts during the session. Tourmaline compositions were determined on polished and carbon-coated sample mounts by wavelength-dispersive electron microprobe analyses using a CAMECA SX-100 electron microprobe at the GFZ in Potsdam. A description of the technique is given by Pal et al. ${ }^{31}$ The electron microprobe data are summarized in Table 2.

\section{Laser ablation MC ICP-MS analysis}

A solid state $213 \mathrm{~nm}$ UV Nd:YAG (New Wave Research, UP213) laser ablation system was used for this study. The laser was operated with laser fluence in the range of $1-3 \mathrm{~J} \mathrm{~cm}^{-2}$ at $10 \mathrm{~Hz}$ repetition rate with a laser spot diameter of $50 \mu \mathrm{m}$ in rastering mode $\left(200 \mu \mathrm{m}\right.$ line, speed of $10 \mu \mathrm{m} \mathrm{s}^{-1}$ and 5 passes over the same raster line). A dynamic laser sampling strategy (laser raster) was employed in order to achieve a stable B signal over the period of the analysis (details of various sample strategies are reviewed in the report of Košler ${ }^{32}$ ). The variable laser fluence was used for sampling different tourmalines in order to maintain similar signal intensities for all samples and standards in the "standard-sample-standard" sequence and to avoid the effects of variable signal intensities on the instrumental mass discrimination ( $c f$. also the observations described in the Results). Samples were ablated in a $\mathrm{He}$ atmosphere $(0.6 \mathrm{~L}$ $\min ^{-1}$ ) with no pre-ablation, using a small volume tear dropshape ablation cell. ${ }^{33}$ The cell washout time was less than $60 \mathrm{~s}$ for the ${ }^{11} \mathrm{~B}$ signal to drop down from $600 \mathrm{mV}$ to the blank level of $2 \mathrm{mV}$. The gas blank was always measured with laser firing and closed shutter (to stabilise the laser beam) for the initial $30 \mathrm{~s}$ of signal acquisition, followed by collection of the ablation signal for additional $100 \mathrm{~s}$. To evaluate the effects of this sampling strategy on the laser-induced isotopic fractionation of $\mathrm{B}$, the sample mount S1 was also analysed using the same ablation parameters in single laser spot mode. In addition, the NIST 610 
Table 2 Electron microprobe data for tourmaline samples analysed in this study. Values are given in wt\%

\begin{tabular}{|c|c|c|c|c|c|c|c|c|}
\hline & Elbaite & Dravite & Schorl & B4 & EZ-272 & JS-82N-1 & JS-82A-1A & EB-67-90 \\
\hline $\mathrm{F}$ & 1.08 & 0.16 & 0.09 & 0.69 & 0.00 & 0.00 & 0.01 & 0.19 \\
\hline $\mathrm{Na}_{2} \mathrm{O}$ & 2.64 & 1.73 & 2.01 & 2.30 & 2.14 & 2.69 & 2.32 & 1.68 \\
\hline $\mathrm{MgO}$ & 1.19 & 8.35 & 0.20 & 0.97 & 9.49 & 5.61 & 6.65 & 8.15 \\
\hline $\mathrm{Al}_{2} \mathrm{O}_{3}$ & 36.81 & 22.71 & 33.33 & 33.35 & 33.32 & 28.97 & 33.03 & 24.39 \\
\hline $\mathrm{Cl}$ & 0.00 & 0.01 & 0.00 & 0.01 & 0.00 & 0.00 & 0.00 & 0.01 \\
\hline $\mathrm{TiO}_{2}$ & 0.35 & 1.53 & 0.67 & 1.13 & 0.53 & 0.12 & 0.67 & 1.37 \\
\hline $\mathrm{FeO}$ & 6.61 & 14.10 & 14.73 & 11.35 & 2.43 & 12.94 & 7.06 & 12.95 \\
\hline $\mathrm{MnO}$ & 0.35 & 0.02 & 1.18 & 1.14 & 0.03 & 0.03 & 0.00 & 0.03 \\
\hline $\mathrm{Cr}_{2} \mathrm{O}_{3}$ & 0.01 & 0.02 & 0.00 & 0.01 & 0.04 & 0.02 & 0.08 & 0.04 \\
\hline $\mathrm{O}=\mathrm{F}$ & -0.45 & -0.07 & -0.04 & -0.29 & 0.00 & 0.00 & -0.01 & -0.08 \\
\hline $\mathrm{O}=\mathrm{Cl}$ & 0.00 & 0.00 & 0.00 & 0.00 & 0.00 & 0.00 & 0.00 & 0.00 \\
\hline
\end{tabular}

glass reference material and tourmaline B4 were also ablated using the rastering mode with laser beam diameters of 30,50 , 80,105 and $120 \mu \mathrm{m}$ in order to evaluate the effect of signal intensity on the measured B isotopic ratios.

The boron isotope ratio measurements were carried out on a Thermo Finnigan Neptune multi-collector ICP-MS equipped with nine Faraday cup detectors. The ${ }^{10} \mathrm{~B}$ and ${ }^{11} \mathrm{~B}$ ion beam intensities were detected on the outermost detectors L4 and $\mathrm{H} 4$, respectively, using a combination of entrance and exit slits that provided a mass resolving power of $M / \Delta M \approx 5500$ (referred to in the instrument software as "medium mass resolution"). Isotopic ratios for each measurement were collected in a single block of data consisting of 260 cycles (each with $0.5 \mathrm{~s}$ integration time) preceded by $25 \mathrm{~s}$ of baseline measurement $(10 \mathrm{~s}$ waiting and $15 \mathrm{~s}$ beam defocus). The instrument parameters are given in Table 3. In the solution mode, the instrument sensitivity for ${ }^{11} \mathrm{~B}$ in $100 \mathrm{ng} \mathrm{g}^{-1} \mathrm{~B}$ solution was $0.16 \mathrm{~V}$ and the corresponding blank level for $2 \% \mathrm{HNO}_{3}$ was $0.0016 \mathrm{~V}$. The signal intensities for all samples analysed in laser ablation mode varied between 0.6 and $0.7 \mathrm{~V}$. The LA MC ICP-MS raw ${ }^{11} \mathrm{~B} /{ }^{10} \mathrm{~B}$ ratios obtained during this study are given in Table 4 .

Data were processed off-line using a LamTool MS Excel spreadsheet. ${ }^{34}$ Following correction of the measured signal intensities for the gas blank, the measured ${ }^{11} \mathrm{~B} /{ }^{10} \mathrm{~B}$ ratio of each unknown sample was corrected for mass discrimination and instrumental drift using the mean of the two adjacent reference material analyses ("standard-sample-standard" bracketing). The instrumental mass discrimination of the measured ${ }^{11} \mathrm{~B} /{ }^{10} \mathrm{~B}$ ratio was typically $14 \%$ and correction for drift during the analytical session varied from 1 to $3 \%$. The drift-corrected ratios were referenced to the published ${ }^{11} \mathrm{~B} /{ }^{10} \mathrm{~B}$ value of the reference material and the results are reported as $\delta^{11} \mathrm{~B}$ values relative to NIST SRM 951 using its certified ${ }^{11} \mathrm{~B} /{ }^{10} \mathrm{~B}$ value of $4.04362 \pm$ 0.00137. ${ }^{4}$ Each tourmaline analysed in this study was treated not only as a sample, but it was also used as a reference material in the standard-sample-standard bracketing sequence, even though none of the materials used here have undergone an ISOcompliant certification of their boron isotope compositions. This means that every measured tourmaline sample was

normalised to all other analysed materials in the same sample mount ( $c f$. Tables 5 and 6). The published values (Table 1) were used as reference values for the calibration. All data used in the calculations of $\delta^{11} \mathrm{~B}$ were obtained during a single analytical session using identical instrument parameters.

The rate of laser-induced boron isotopic fractionation during the single laser spot LA MC ICP-MS measurement was evaluated using the method of Sylvester and Ghaderi ${ }^{36}$ and the slope of the least square linear trend fitted to the blank-corrected values of isotope ratios plotted against the time of acquisition. ${ }^{35}$ Identical signal lengths, corresponding to 800 laser pulses (equivalent to

Table 3 Instrument and data acquisition parameters for laser ablation (New Wave Research UP-213) and solution MC ICP-MS (Thermo Finnigan Neptune) analyses

Laser wavelength

Laser fluence

Repetition rate

Beam diameter

Ablation mode

Measured masses

Mass resolution

Nebulizer

Spray chamber

$$
\begin{aligned}
& 213 \mathrm{~nm} \text { (Nd:YAG) } \\
& \text { 1-3 } \mathrm{J} \mathrm{cm}^{-2} \\
& 10 \mathrm{~Hz} \\
& 50 \mu \mathrm{m}
\end{aligned}
$$

\begin{tabular}{|c|c|c|}
\hline & Laser & Solution \\
\hline RF power [W] & 1250 & 1250 \\
\hline Cool gas $\left[\mathrm{L} \mathrm{min}{ }^{-1}\right]$ & 15 & 15 \\
\hline Auxiliary gas $\left[\mathrm{L} \mathrm{min}{ }^{-1}\right]$ & 0.95 & 0.95 \\
\hline Sample Ar gas $\left[\mathrm{L} \mathrm{min}^{-1}\right]$ & 1.20 & 1.19 \\
\hline Laser carrier He gas $\left[\mathrm{L} \mathrm{min}{ }^{-1}\right]$ & 0.60 & 0.00 \\
\hline Extraction lens $[\mathrm{V}]$ & -2000 & -2000 \\
\hline Focus lens $[\mathrm{V}]$ & -708 & -708 \\
\hline$X$ deflection lens $[\mathrm{V}]$ & -6.73 & -5.86 \\
\hline$Y$ deflection lens $[\mathrm{V}]$ & 1.07 & -0.46 \\
\hline Shape lens $[\mathrm{V}]$ & 197 & 210 \\
\hline
\end{tabular}

Sensitivity [mV] Background [mV]
160 on mass 11 for $100 \mathrm{ppb} B$ 1.6 on mass 11 
Table 4 Compilation of all LA MC ICP-MS data obtained during this study. The raw ${ }^{11} \mathrm{~B} /{ }^{10} \mathrm{~B}$ ratios in this table are corrected for gas blank only

\begin{tabular}{|c|c|c|c|c|c|}
\hline \multirow[b]{2}{*}{ Sample } & \multicolumn{2}{|c|}{ Sample mount S1 } & \multirow[b]{2}{*}{ Sample } & \multicolumn{2}{|c|}{ Sample mount S2 } \\
\hline & ${ }^{11} \mathrm{~B} /{ }^{10} \mathrm{~B}$ & $2 \mathrm{SE}$ & & ${ }^{11} \mathrm{~B} /{ }^{10} \mathrm{~B}$ & $2 \mathrm{SE}$ \\
\hline \multirow[t]{10}{*}{ Elbaite } & 4.5738 & 0.0006 & \multirow[t]{5}{*}{ Elbaite } & 4.5732 & 0.0008 \\
\hline & 4.5777 & 0.0006 & & 4.5720 & 0.0009 \\
\hline & 4.5791 & 0.0007 & & 4.5682 & 0.0006 \\
\hline & 4.5751 & 0.0006 & & 4.5673 & 0.0008 \\
\hline & 4.5750 & 0.0007 & & 4.5675 & 0.0008 \\
\hline & 4.5777 & 0.0006 & \multirow[t]{5}{*}{ Dravite } & 4.5985 & 0.0010 \\
\hline & 4.5800 & 0.0006 & & 4.5989 & 0.0008 \\
\hline & 4.5745 & 0.0006 & & 4.5975 & 0.0008 \\
\hline & 4.5713 & 0.0007 & & 4.5966 & 0.0010 \\
\hline & 4.5723 & 0.0006 & & 4.5961 & 0.0007 \\
\hline \multirow[t]{10}{*}{ Dravite } & 4.5969 & 0.0007 & \multirow[t]{5}{*}{ EZ-272 } & 4.5635 & 0.0006 \\
\hline & 4.6021 & 0.0007 & & 4.5620 & 0.0011 \\
\hline & 4.6013 & 0.0006 & & 4.5635 & 0.0007 \\
\hline & 4.5978 & 0.0008 & & 4.5608 & 0.0008 \\
\hline & 4.5985 & 0.0007 & & 4.5575 & 0.0006 \\
\hline & 4.6016 & 0.0007 & \multirow[t]{5}{*}{ JS-82N-1 } & 4.6201 & 0.0005 \\
\hline & 4.5998 & 0.0007 & & 4.6187 & 0.0007 \\
\hline & 4.5970 & 0.0007 & & 4.6155 & 0.0006 \\
\hline & 4.5971 & 0.0008 & & 4.6150 & 0.0006 \\
\hline & 4.5967 & 0.0009 & & 4.6186 & 0.0005 \\
\hline \multirow[t]{10}{*}{ Schorl } & 4.5671 & 0.0006 & \multirow[t]{3}{*}{ JS- $82 A-1 A$} & 4.5369 & 0.0005 \\
\hline & 4.5695 & 0.0006 & & 4.5343 & 0.0008 \\
\hline & 4.5688 & 0.0006 & & 4.5320 & 0.0006 \\
\hline & 4.5683 & 0.0006 & \multirow[t]{3}{*}{ EB-67-90 } & 4.6789 & 0.0008 \\
\hline & 4.5682 & 0.0007 & & 4.6785 & 0.0005 \\
\hline & 4.5708 & 0.0007 & & 4.6754 & 0.0006 \\
\hline & 4.5659 & 0.0005 & & & \\
\hline & 4.5661 & 0.0006 & & \multirow{2}{*}{\multicolumn{2}{|c|}{$\begin{array}{l}\text { Sample mount S1 } \\
\text { (spot analysis) }\end{array}$}} \\
\hline & 4.5660 & 0.0006 & & & \\
\hline & 4.5645 & 0.0006 & & & \\
\hline \multirow[t]{10}{*}{ B4 } & 4.5874 & 0.0007 & Sample & ${ }^{11} \mathrm{~B} /{ }^{10} \mathrm{~B}$ & $2 \mathrm{SE}$ \\
\hline & 4.5894 & 0.0007 & & & \\
\hline & 4.5871 & 0.0008 & \multirow[t]{2}{*}{ Elbaite } & 4.5722 & 0.0009 \\
\hline & 4.5855 & 0.0008 & & 4.5701 & 0.0009 \\
\hline & 4.5869 & 0.0009 & \multirow[t]{2}{*}{ Dravite } & 4.5948 & 0.0014 \\
\hline & 4.5897 & 0.0007 & & 4.5937 & 0.0012 \\
\hline & 4.5851 & 0.0006 & \multirow[t]{2}{*}{ Schorl } & 4.5607 & 0.0011 \\
\hline & 4.5855 & 0.0006 & & 4.5632 & 0.0010 \\
\hline & 4.5853 & 0.0006 & \multirow[t]{2}{*}{ B4 } & 4.5814 & 0.0010 \\
\hline & 4.5839 & 0.0007 & & 4.5826 & 0.0010 \\
\hline
\end{tabular}

80 seconds of ablation), were used to calculate the slope of time dependent fractionation for all analyses.

\section{SIMS analysis}

All samples were analysed for boron isotope ratios using the Cameca ims 6f SIMS at the Helmholtz Centre in Potsdam, Germany. A ${ }^{16} \mathrm{O}^{-}$primary ion beam employing a nominal accelerating voltage of $12.5 \mathrm{kV}$ with a total ion current of $800 \mathrm{pA}$ was used to produce positive secondary ions. The beam was focused to $\sim 5 \mu \mathrm{m}$ diameter at the sample surface. A secondary extraction voltage of $10 \mathrm{kV}$ was used. The instrument was operated at a mass resolution $M / \Delta M \approx 1150$ to ensure full separation between the ${ }^{11} \mathrm{~B}^{+}$and the isobaric ${ }^{10} \mathrm{~B}^{1} \mathrm{H}^{+}$mass peaks. Measured isotopic ratios were based on five blocks of 20
Table 5 Calculated $\delta^{11} \mathrm{~B}$ values (in \% relative to NIST SRM 951) for the samples contained in mount S1 as determined by LA MC ICP-MS. The samples were normalised by standard-sample-standard bracketing approach. The mean values represent weighted average of $\delta^{11} \mathrm{~B} \pm 1 \mathrm{~s}$

\begin{tabular}{|c|c|c|c|c|c|c|c|c|}
\hline \multirow[b]{3}{*}{ Sample } & \multicolumn{8}{|c|}{ Normalized to } \\
\hline & \multicolumn{2}{|l|}{ Elbaite } & \multicolumn{2}{|l|}{ Dravite } & \multicolumn{2}{|l|}{ Schorl } & \multicolumn{2}{|l|}{ B4 } \\
\hline & $\delta^{11} \mathrm{~B}$ & $2 \mathrm{~s}$ & $\delta^{11} \mathrm{~B}$ & $2 \mathrm{~s}$ & $\delta^{11} \mathrm{~B}$ & $2 \mathrm{~s}$ & $\delta^{11} \mathrm{~B}$ & $2 \mathrm{~s}$ \\
\hline \multirow[t]{9}{*}{ Elbaite } & -10.1 & 0.2 & -11.3 & 0.2 & -10.5 & 0.2 & -11.0 & 0.2 \\
\hline & -10.8 & 0.2 & -11.5 & 0.2 & -10.4 & 0.2 & -10.7 & 0.2 \\
\hline & -10.4 & 0.2 & -11.9 & 0.2 & -11.1 & 0.2 & -11.1 & 0.2 \\
\hline & -10.7 & 0.2 & -11.6 & 0.2 & -11.1 & 0.2 & -11.1 & 0.2 \\
\hline & & & -11.4 & 0.2 & -10.7 & 0.2 & -11.0 & 0.2 \\
\hline & & & -11.1 & 0.2 & -10.0 & 0.2 & -10.3 & 0.2 \\
\hline & & & -11.7 & 0.2 & -10.7 & 0.2 & -11.1 & 0.2 \\
\hline & & & -12.2 & 0.2 & -11.4 & 0.2 & -11.8 & 0.2 \\
\hline & & & -11.9 & 0.2 & -11.0 & 0.2 & -11.4 & 0.2 \\
\hline $\begin{array}{l}\text { Mean } \\
\text { Difference }\end{array}$ & \multicolumn{2}{|c|}{$-\mathbf{1 0 . 5} \pm \mathbf{0 . 3}$} & \multicolumn{2}{|c|}{$\begin{aligned}-11.6 & \pm 0.3 \\
1.1 & \end{aligned}$} & \multicolumn{2}{|c|}{$\begin{aligned}-10.7 & \pm 0.4 \\
0.2 & \end{aligned}$} & \multicolumn{2}{|c|}{$\begin{aligned}-11.0 & \pm 0.4 \\
0.5 & \end{aligned}$} \\
\hline \multirow[t]{9}{*}{ Dravite } & -5.8 & 0.2 & -6.5 & 0.2 & -5.2 & 0.2 & -5.7 & 0.2 \\
\hline & -5.3 & 0.2 & -6.8 & 0.2 & -5.5 & 0.2 & -5.9 & 0.2 \\
\hline & -5.2 & 0.2 & -6.7 & 0.2 & -6.2 & 0.2 & -6.2 & 0.2 \\
\hline & -5.5 & 0.2 & -6.9 & 0.2 & -6.0 & 0.2 & -6.0 & 0.2 \\
\hline & -5.6 & 0.2 & & & -5.6 & 0.2 & -5.8 & 0.2 \\
\hline & -5.5 & 0.2 & & & -5.7 & 0.2 & -6.0 & 0.2 \\
\hline & -5.5 & 0.2 & & & -5.8 & 0.2 & -6.2 & 0.2 \\
\hline & -5.2 & 0.2 & & & -5.8 & 0.2 & -6.2 & 0.2 \\
\hline & -4.9 & 0.2 & & & -5.7 & 0.2 & -6.1 & 0.2 \\
\hline Mean & \multicolumn{2}{|c|}{$-5.4 \pm 0.3$} & \multicolumn{2}{|c|}{$-6.7 \pm 0.2$} & \multicolumn{2}{|c|}{$-5.7 \pm 0.3$} & \multirow{2}{*}{\multicolumn{2}{|c|}{$-6.0 \pm 0.2$}} \\
\hline Difference & -1.3 & & & & -1.0 & & & \\
\hline \multirow[t]{9}{*}{ Schorl } & -12.3 & 0.2 & -13.6 & 0.2 & -12.4 & 0.2 & -12.8 & 0.2 \\
\hline & -12.3 & 0.2 & -13.6 & 0.2 & -12.7 & 0.2 & -12.9 & 0.2 \\
\hline & -12.2 & 0.2 & -13.2 & 0.2 & -12.1 & 0.2 & -12.6 & 0.2 \\
\hline & -11.8 & 0.2 & -13.0 & 0.2 & -12.5 & 0.2 & -12.6 & 0.2 \\
\hline & -12.1 & 0.2 & -13.5 & 0.2 & & & -12.5 & 0.2 \\
\hline & -12.1 & 0.2 & -13.1 & 0.2 & & & -13.4 & 0.2 \\
\hline & -12.9 & 0.2 & -13.6 & 0.2 & & & -12.9 & 0.2 \\
\hline & -11.9 & 0.2 & -13.3 & 0.2 & & & -12.9 & 0.2 \\
\hline & -11.6 & 0.2 & -13.3 & 0.2 & & & -13.1 & 0.2 \\
\hline Mean & \multicolumn{2}{|c|}{$-12.2 \pm 0.4$} & \multicolumn{2}{|c|}{$-13.4 \pm 0.2$} & \multicolumn{2}{|c|}{$-12.4 \pm 0.2$} & \multicolumn{2}{|c|}{$-12.9 \pm 0.3$} \\
\hline Difference & -0.2 & & 1.0 & & & & 0.5 & \\
\hline \multirow[t]{9}{*}{ B4 } & -7.9 & 0.2 & -9.2 & 0.2 & -8.4 & 0.2 & -8.2 & 0.2 \\
\hline & -8.0 & 0.2 & -9.2 & 0.2 & -8.1 & 0.2 & -9.0 & 0.2 \\
\hline & -8.2 & 0.2 & -9.3 & 0.2 & -8.5 & 0.2 & -9.2 & 0.2 \\
\hline & -8.1 & 0.2 & -9.3 & 0.2 & -8.8 & 0.2 & -8.6 & 0.2 \\
\hline & -8.1 & 0.2 & -9.4 & 0.2 & -8.7 & 0.2 & & \\
\hline & -8.1 & 0.2 & -9.0 & 0.2 & -7.9 & 0.2 & & \\
\hline & -8.7 & 0.2 & -9.5 & 0.2 & -8.4 & 0.2 & & \\
\hline & -7.7 & 0.2 & -9.1 & 0.2 & -8.3 & 0.2 & & \\
\hline & -7.5 & 0.2 & -9.1 & 0.2 & -8.2 & 0.2 & & \\
\hline Mean & $-8.0=$ & 0.4 & $-9.2=$ & $=0.2$ & -8.3 & 0.3 & -8.8 & $=0.4$ \\
\hline Difference & -0.8 & & 0.5 & & -0.5 & & & \\
\hline
\end{tabular}

cycles of measurement consisting of $2 s$ and $1 s$ integrations of ${ }^{10} \mathrm{~B}^{+}$and ${ }^{11} \mathrm{~B}^{+}$, respectively, resulting in a total analysis time of about 11 minutes. During the two days of data collection we found no time-dependent trend in the measured values on the four calibrants (dravite, elbaite, schorl and B4), the overall mass discrimination of the SIMS method was defined by the simple average of the observed fractionation during the two days of data acquisition $(n=29)$. 
Table 6 Calculated $\delta^{11} \mathrm{~B}$ values (in \% relative to NIST SRM 951) for the samples contained in mount S2 as determined by LA MC ICP-MS. The samples were normalised by standard-sample-standard bracketing approach. The mean values represent weighted average of $\delta^{11} \mathrm{~B} \pm 1 \mathrm{~s}$

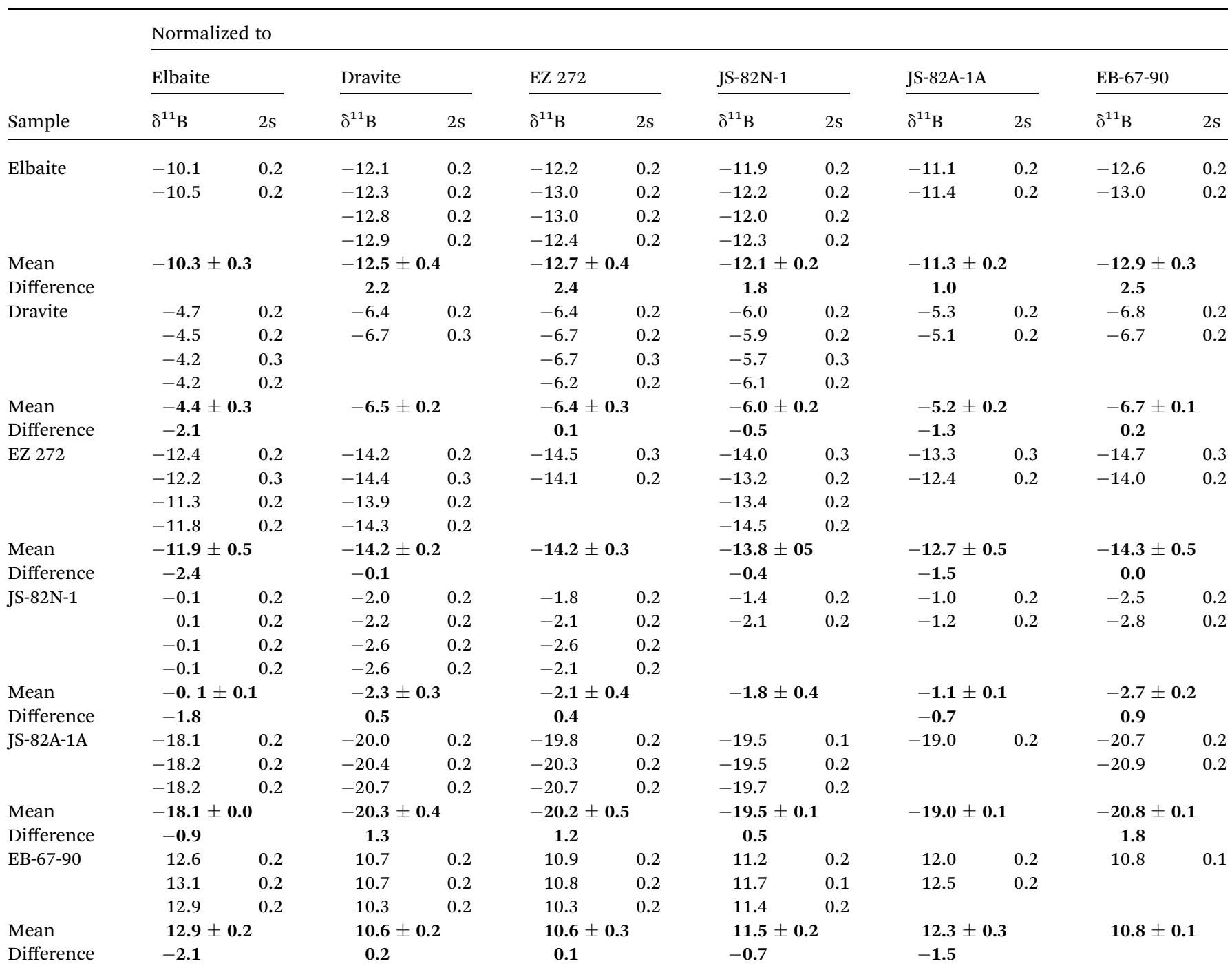

\section{Uncertainty calculations and LA MC ICP-MS and SIMS data comparison}

Different masses (volumes) of samples typically analysed by LA MC ICP-MS and SIMS and different data acquisition and data reduction methods developed for the two techniques make it difficult to directly compare their analytical uncertainties. The terminology and definitions of uncertainties used here follow the recommendation by Potts. ${ }^{37}$ Briefly, the analysis of boron isotopic composition by LA MC ICP-MS was based on a standard-sample-standard bracketing data acquisition procedure that corrects the measured isotopic ratios for mass discrimination and instrumental drift. Analytical uncertainties of individual reference material and sample measurements were combined by quadratic addition, thereby providing an estimate of measurement repeatability; accordingly, only a series of three consecutive measurements contributed to the uncertainty of the $\delta^{11} \mathrm{~B}$ values listed in Tables 4-6. The weighted mean of $\delta^{11} \mathrm{~B}$ values for each sample with the corresponding standard deviation were used to assess the trueness (accuracy) of the measurement.

In contrast to LA MC ICP-MS, the SIMS boron isotope data acquisition and reduction followed the procedures routinely used in the Cameca $6 \mathrm{f}$ SIMS laboratory of the Helmholtz Centre in Potsdam..$^{26,27,38-41}$ Data from SIMS were corrected for mass discrimination and checked for instrumental drift using the mass discrimination factor $\left(\Delta_{\text {inst }}\right)$ calculated as a ratio between the measured and reference ${ }^{11} \mathrm{~B} /{ }^{10} \mathrm{~B}$ values. This factor was defined by the mean of all $(n=29)$ analyses of the four tourmaline reference materials used in this study. Because all sample data were corrected by a single $\Delta_{\text {inst }}$ factor, the repeatability of the reported $\delta^{11} \mathrm{~B}$ values necessarily includes any possible matrix effect resulting from differences in the chemical compositions of the reference materials, any influence derived from sample changing and over-night instrument shutdown. Compared to the LA MC ICP-MS procedure, this approach typically results in a larger repeatability estimate and represents a somewhat more robust method. We appreciate the rationale 
of different strategies for data acquisition and reduction in $\mathrm{B}$ isotopic analysis by LA MC ICP-MS and SIMS, but we have also recalculated both datasets using the SIMS approach as described above (see Discussion). While we recognize that this procedure may not be optimal for the LA MC ICP-MS data, it provides an alternative way of data and uncertainty comparison between LA MC ICP-MS and SIMS.

\section{Results}

Electron microprobe analyses (Table 2) revealed three compositionally distinct tourmaline groups within the $\mathrm{Al}-\mathrm{Fe}_{(\mathrm{tot})}-\mathrm{Mg}$ ternary diagram (Fig. 1): (1) 98144 elbaite from a granitic pegmatite, (2) the schorl group consisting of 112566 schorl from a granitic pegmatite and B4 tourmaline from a monzogranitic pegmatite, and (3) the chemically uniform dravite group consisting of the 108796 dravite of uncertain origin (detrital source) and metamorphic (amphibolite facies) tourmaline EB-67-90. The chemical compositions of the other three metamorphic tourmalines classified as dravite EZ-272 (amphibolite facies), dravite JS-82A-1A (granulite facies) and schorl JS-82N-1 (greenschist facies) ${ }^{\mathbf{4 2}}$ show a considerable variation.

The inspection of the time-resolved signal intensity ratio of boron isotopes reveals no significant laser-induced time dependent isotopic fractionation (systematic change of the measured isotopic ratio with number of laser pulses applied to the sample) for either of the laser ablation sampling strategies. The calculated slopes of the respective regression lines through the time-resolved single laser spot and laser raster ablation data are zero (within 1 sigma uncertainty of the measurement). The mean values of the time resolved ${ }^{11} \mathrm{~B} /{ }^{10} \mathrm{~B}$ isotope ratio patterns obtained for the two laser ablation sampling modes are also statistically identical.

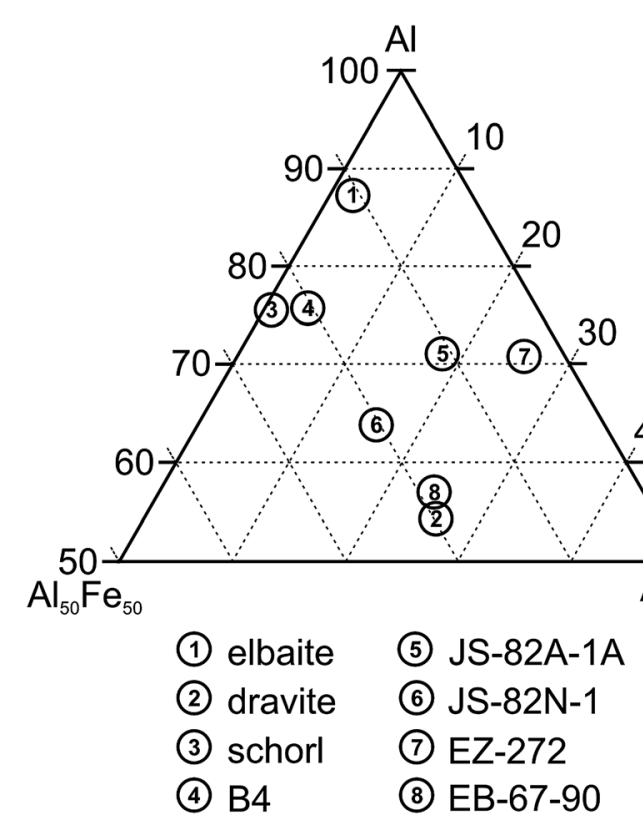

Fig. 1 Composition of samples (electron microprobe data) in Al$\mathrm{Fe}_{\text {(tot) }}-\mathrm{Mg}$ diagram.
The mass spectrum obtained from a $100 \mathrm{ng} \mathrm{g}^{-1}$ boron solution of SRM 951 that was scanned at three different mass resolutions was used to evaluate potential effects of spectral interferences on the measured isotopic ratios (Fig. 2A). No interferences were detected on mass 11 , in contrast there was an interference detected on the low mass side of the ${ }^{10} \mathrm{~B}$ peak. However, when operating the MC ICP-MS at a mass resolving power of $M / \Delta M \approx 5500$, the ${ }^{10} \mathrm{~B}$ peak was fully resolved from the interference. The data compiled in Fig. 2B show that the relative signal intensity of the interfering species was likely related to the temperature in the sampled part of the ICP, since the sample gas flow rate was clearly linked to the intensity of the interfering peak. In solution mode the sample gas flow was increased in five steps between 1.115 and $1.295 \mathrm{~L} \mathrm{~min}^{-1}$ of argon and the relative intensity of the interference on mass 10 during the experiment decreased with increasing sample gas flow; the optimum sample gas flow (i.e., minimum interference overlap with the ${ }^{10} \mathrm{~B}$ peak and sufficiently high $\mathrm{B}$ signal intensity) was $c a .1 .2 \mathrm{~L} \mathrm{~min}^{-1}$. In laser ablation mode, the rate of $\mathrm{Ar}$ gas flow was fixed to $1.2 \mathrm{~L} \mathrm{~min}^{-1}$ while the flow rate of $\mathrm{He}$ in the ablation cell was adjusted in 9 steps between 0.45 and $0.8 \mathrm{~L}$ $\min ^{-1}$ to test whether this effect was consistent also for "dry" aerosol. During this experiment the optimum He gas flow was ca. $0.65 \mathrm{~L} \mathrm{~min}^{-1}$. In general, the signal intensity of the interfering species decreased with increasing sample Ar gas (or laser carrier He gas) that lowered the temperature in the central channel of the ICP, which is consistent with the interference of multiply charged atom (such as $\mathrm{Ar}^{4+}$ ) rather than a polyatomic ion.

In addition, to assess the effect of $\mathrm{B}$ concentration (signal intensity) on the measured B isotopic ratios, we performed a series of solution (NIST SRM 951) and laser ablation (B4, NIST 610) analyses. The results shown in Fig. 3 suggest that with increasing boron concentration in the solution of NIST SRM 951 $\left(10,50,100,150,200,250,300,400\right.$ and $500 \mathrm{ng} \mathrm{g}^{-1}$, corresponding to the ${ }^{11} \mathrm{~B}$ signal intensity range of $0.012-0.532 \mathrm{~V}$ ), there is a shift of up to $\sim 30 \%$ owards the heavy measured $\mathrm{B}$ isotopic ratios. A corresponding pattern of B isotopic shift with changing signal intensity was also observed for laser ablation analysis. The signal intensity was varied from $0.128 \mathrm{~V}$ to $2.437 \mathrm{~V}$ and from $0.003 \mathrm{~V}$ to $0.058 \mathrm{~V}$ for the tourmaline $\mathrm{B} 4$ and glass NIST 610, respectively, by increasing the amount of ablated sample through changing the laser beam diameter $(30,50,80$, 105 and $120 \mu \mathrm{m})$. The respective isotopic shifts towards a heavy measured B isotopic composition were ca. 15 and $170 \%$, and this effect was more pronounced for low B concentrations and low signal intensities.

The results of $\mathrm{B}$ isotopic analysis of tourmaline by LA MC ICP-MS are summarized in Table 4, the calculated $\delta^{11} \mathrm{~B}$ values (relative to NIST SRM 951) for the samples normalised by the standard-sample-standard bracketing approach are given in Tables 5 and 6 for sample mounts S1 and S2, respectively. The Palmer and Slack tourmaline samples that were normalised to analyses of the same material yielded the following weighted average $\delta^{11} \mathrm{~B}$ values $( \pm 1 s):-14.24 \pm 0.28 \%$ (sample EZ-272), $-1.79 \pm 0.45 \%$ o (sample JS-82N-1), $-19.02 \pm 0.1 \%$, (sample JS$82 \mathrm{~A}-1 \mathrm{~A}$ ) and $10.76 \pm 0.1 \%$ (sample EB-67-90). The 

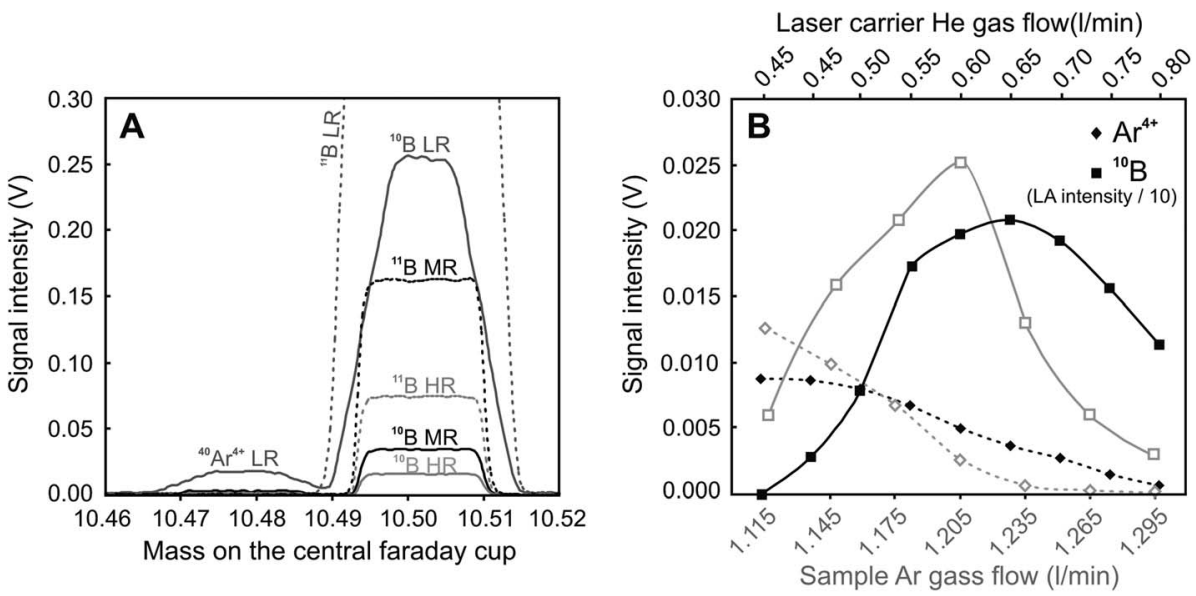

Fig. 2 (A) mass scans of $100 \mathrm{ng} \mathrm{g}^{-1}$ boron SRM 951 solution in $2 \% \mathrm{v} / \mathrm{v} \mathrm{HNO} 3$ at three different values of mass resolving power ( $M / \Delta M$ ) showing interfering peak of ${ }^{40} \mathrm{Ar}^{4+}$ on the low mass side of the ${ }^{10} \mathrm{~B}$ peak ( $\mathrm{LR}-$ low resolution, $M / \Delta M \sim 300, \mathrm{MR}-$ medium resolution, $M / \Delta M \sim 5500, \mathrm{HR}-$ high resolution, $M / \Delta M \sim 6000$. The signal intensity of ${ }^{11} \mathrm{~B}$ in $L R$ is $1.2 \mathrm{~V}$ ). (B) Intensity of ${ }^{10} \mathrm{~B}$ (solid line, intensity of la data was divided by a factor of 10 ) and interfering ${ }^{40} \mathrm{Ar}^{4+}$ (dashed line) signals in medium mass resolution $(M / \Delta M \sim 5500$ ) for different sample gas flow settings. Data for laser ablation of tourmaline B4 correspond to solid black symbols, data for analysis of $100 \mathrm{ng} \mathrm{g}^{-1}$ boron SRM 951 solution in $2 \% \mathrm{v} / \mathrm{v} \mathrm{HNO} 3$ are shown by open grey symbols. See text and Table 3 for instrument parameters. Note that data for (A) and (B) were acquired during different analytical sessions and show small differences in the corresponding signal intensities.

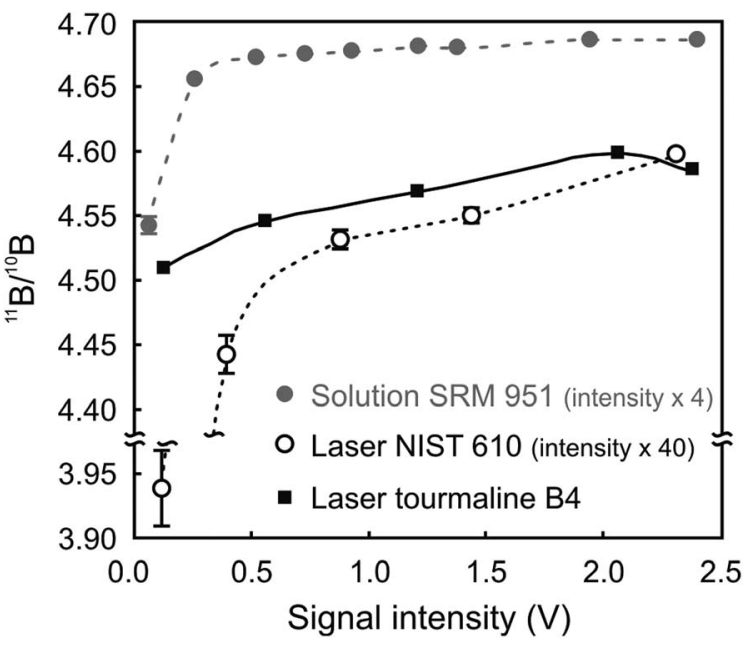

Fig. 3 Effect of signal intensity on the measured boron isotopic ratio in standard solution SRM 951 and laser ablation of NIST 610 and B4 tourmaline (see text for details). Measured signal intensities of SRM 951 and NIST 610 were multiplied by factors to obtain plots at similar scale as for the B4 tourmaline.

corresponding weighted average $\delta^{11} \mathrm{~B}$ values for 98144 elbaite, 108796 dravite, 112566 schorl and B4 were $-10.45 \pm 0.28 \%$, $-6.64 \pm 0.22 \%,-12.41 \pm 0.25$ and $-8.77 \pm 0.41 \%$, respectively. Boron isotopic data obtained by SIMS are summarized in Table 7.

\section{Discussion}

\section{A. Laser ablation MC ICP-MS matrix effects}

Isobaric interferences, such as those caused by polyatomic ions generated within the ICP source, can affect both the trueness and precision of the isotope ratio determination. The observed interference on the low mass side of the ${ }^{10} \mathrm{~B}$ peak
(Fig. 2) has been attributed to ${ }^{40} \mathrm{Ar}^{4+}{ }^{41,18,43,44}$ Although Le Roux et al. ${ }^{15}$ reported that similar interferences can be caused by ${ }^{20} \mathrm{Ne}^{2+}$, we did not observe any significant traces of Ne during our experiments. The production of ${ }^{40} \mathrm{Ar}^{4+}$ is, to a large extent, controlled by plasma temperature, which in turn is affected by parameters such as RF power, sample gas flow, solvent loading and RF generator characteristics. ${ }^{45}$ Gäbler and Bahr ${ }^{11}$ reported that the intensity of ${ }^{40} \mathrm{Ar}^{4+}$ interference can be reduced by using a lower radio frequency setting, which is one of the fundamental parameters that influence the ICP temperature. The results of our study are consistent with those in ref. 11 in that the ability of plasma to form quadruply charged Ar ions appears to be mainly influenced by the ICP temperature. This is in agreement with the observed change in the ${ }^{40} \mathrm{Ar}^{4+}$ intensity relative to the intensity of ${ }^{10} \mathrm{~B}$ with varying sample gas flows (Fig. 2B).

The observed shift towards heavier measured isotopic ratios with increasing signal intensity (total ion concentration in the plasma ion source, Fig. 3) is attributed mainly to the space charge effects induced by electrostatic interactions between positively charged ions in the ICP as well as in the interface region. The space charge effect is influenced by the density and composition of the ion cloud, and is therefore related to the composition of the sample matrix and concentration of the analyte. ${ }^{46}$ The small decrease of the measured B isotopic ratio in the B4 tourmaline corresponding to the highest signal intensity (ablation with $120 \mu \mathrm{m}$ laser beam diameter, Fig. 3) is the only observed exception from this trend. While there is no visible laser-induced fractionation (Fig. 4) that could possibly explain this decrease, it may be consistent with effects of the plasma mass load, since the previously published data ${ }^{47}$ suggest that an increase in the mass loading of the ICP can lead to changes in the measured intensity ratios.

Our experiments revealed an apparent variation in the B isotopic composition of tourmalines as a function of the 
Table 7 Compilation of SIMS data for the tourmaline reference materials of different compositions. The uncertainties represent $1 \mathrm{~s}$ of the reported populations. $\Delta_{\text {inst }}$ - instrument mass discrimination. Measured values marked by asterisk were obtained during the second analytical session (different day)

\begin{tabular}{|c|c|c|c|c|c|}
\hline & Measured & & Corrected & & \\
\hline Sample & ${ }^{11} \mathrm{~B} /{ }^{10} \mathrm{~B}$ & $\Delta_{\text {inst }}$ & ${ }^{11} \mathrm{~B} /{ }^{10} \mathrm{~B}$ & $\delta^{11} \mathrm{~B}$ & $1 s$ \\
\hline \multirow[t]{7}{*}{ Elbaite } & 3.916 & 0.97866 & 3.996 & -11.8 & 0.4 \\
\hline & 3.910 & 0.97716 & 3.990 & -13.3 & 0.3 \\
\hline & 3.911 & 0.97741 & 3.991 & -13.1 & 0.3 \\
\hline & 3.916 & 0.97866 & 3.996 & -11.8 & 0.3 \\
\hline & $3.920^{*}$ & 0.97966 & 4.000 & -10.8 & 0.3 \\
\hline & $3.923^{*}$ & 0.98041 & 4.003 & -10.0 & 0.3 \\
\hline & $3.919 *$ & 0.97941 & 3.999 & -11.1 & 0.3 \\
\hline Mean & \multicolumn{3}{|c|}{$0.97876 \pm 0.00118$} & \multicolumn{2}{|l|}{$-11.7 \pm 1.2$} \\
\hline \multirow{4}{*}{ Dravite } & 3.940 & 0.98086 & 4.020 & -5.8 & 0.4 \\
\hline & 3.933 & 0.97911 & 4.013 & -7.5 & 0.3 \\
\hline & 3.934 & 0.97936 & 4.014 & -7.3 & 0.6 \\
\hline & $3.933^{*}$ & 0.97911 & 4.013 & -7.5 & 0.4 \\
\hline Mean & \multicolumn{3}{|c|}{$0.97961 \pm 0.00083$} & \multicolumn{2}{|l|}{$-7.0 \pm 0.8$} \\
\hline \multirow[t]{6}{*}{ Schorl } & 3.916 & 0.98069 & 3.996 & -11.8 & 0.3 \\
\hline & 3.912 & 0.97969 & 3.992 & -12.8 & 0.4 \\
\hline & $3.919^{*}$ & 0.98144 & 3.999 & -11.1 & 0.3 \\
\hline & $3.914^{*}$ & 0.98019 & 3.994 & -12.3 & 0.4 \\
\hline & $3.914^{*}$ & 0.98019 & 3.994 & -12.3 & 0.4 \\
\hline & $3.920^{*}$ & 0.98169 & 4.000 & -10.8 & 0.4 \\
\hline Mean & \multicolumn{3}{|c|}{$0.98065 \pm 0.00078$} & \multicolumn{2}{|l|}{$-11.9 \pm 0.8$} \\
\hline \multirow[t]{12}{*}{ B4 } & 3.928 & 0.98009 & 4.008 & -8.8 & 0.4 \\
\hline & 3.935 & 0.98184 & 4.015 & -7.0 & 0.4 \\
\hline & 3.934 & 0.98159 & 4.014 & -7.3 & 0.4 \\
\hline & $3.931^{*}$ & 0.98084 & 4.011 & -8.0 & 0.4 \\
\hline & $3.923^{*}$ & 0.97884 & 4.003 & -10.0 & 0.4 \\
\hline & $3.921^{*}$ & 0.97834 & 4.001 & -10.6 & 0.4 \\
\hline & $3.933^{*}$ & 0.98134 & 4.013 & -7.5 & 0.3 \\
\hline & $3.937 *$ & 0.98233 & 4.017 & -6.5 & 0.4 \\
\hline & $3.934^{*}$ & 0.98159 & 4.014 & -7.3 & 0.4 \\
\hline & $3.926^{*}$ & 0.97959 & 4.006 & -9.3 & 0.3 \\
\hline & $3.928^{*}$ & 0.98009 & 4.008 & -8.8 & 0.4 \\
\hline & $3.929^{*}$ & 0.98034 & 4.009 & -8.5 & 0.4 \\
\hline Mean & \multicolumn{3}{|c|}{$0.98057 \pm \mathbf{0 . 0 0 1 2 4}$} & \multicolumn{2}{|l|}{$-8.3 \pm 1.3$} \\
\hline Overall mean & \multicolumn{3}{|c|}{$0.98002 \pm 0.00131$} & & \\
\hline
\end{tabular}

different reference materials used for calibration. When calibrated against a tourmaline reference material of similar chemical composition, the isotopic composition agreed with the reference TIMS values (Fig. 5). The offset between the measured and reference $\delta^{11} \mathrm{~B}$ values (in \%o) correlates well with the chemical composition of the reference material, which is indicative of a systematic chemical matrix effect. The offset from the reference value for specific compositions of the RMs is maintained for all measured samples, as can be seen from the offset patterns shown in Fig. 5. The maximum difference of $2.5 \%$ was observed between elbaite and dravite tourmalines (Fig. 5B and Table 6) and the smallest difference of $c a .0 .1 \%$ (i.e., within analytical uncertainty) was observed between dravite composition tourmalines (Fig. 5B and Table 6).

In light of the highly complex solid-solutions possible in the tourmaline system ${ }^{48}$ it is difficult to assign the observed matrix effect to any particular parameter of the tourmaline chemical composition. Chaussidon and Albarède ${ }^{49}$ reported for their SIMS measurements a systematic decrease in $\delta^{11} \mathrm{~B}$ from the Lirich tourmalines to the Mg-rich and the Fe-rich tourmalines. Comparison of the chemical composition of tourmaline (Fig. 1) with the measured boron isotopic ratios (Tables 5 and 6) suggests that the $\delta^{11} \mathrm{~B}$ values of the samples are mainly influenced by differences in the $\mathrm{Al}$ content between the samples and the tourmaline RMs (the observed $\delta^{11} \mathrm{~B}$ values decrease with increasing $\mathrm{Al}$ content in the tourmaline calibration material). While we do not assume an analogous response to variations in the matrix composition between LA MC ICP-MS and SIMS techniques, our observation seems to be consistent with the results of Chaussidon and Albarède ${ }^{49}$ because the compositional field of Li-rich tourmalines in the $\mathrm{Al}-\mathrm{Fe}_{(\text {tot }}-\mathrm{Mg}$ ternary diagram is the closest one to the $\mathrm{Al}$ apex. In addition, when $\mathrm{Al}$ contents in the tourmaline sample and the tourmaline used for calibration are similar, there is a significant correlation between increasing $\mathrm{Fe} /(\mathrm{Fe}+\mathrm{Mg})$ ratio and the shift in $\delta^{11} \mathrm{~B}$ towards isotopically lighter compositions. All tourmalines from the dravite group with similar $\mathrm{Mg}$ contents (dravite, EB-67-90, EZ-272) show similar matrix effects, despite substantial differences in the composition (namely the contents of $\mathrm{Al}, \mathrm{Ca}, \mathrm{Ti}$ and Fe) between EZ-272 and the rest of the dravite group ( $c f$. Table 2). The isotopic composition of boron in the four tourmaline reference materials (98144 elbaite, 108796 dravite, 112566 schorl and B4) that is shown graphically in Fig. 6 suggests that the matrix-matched LA MC ICP-MS data obtained in this study are in close agreement with the previously published P-TIMS values for the isotopic composition of these reference samples by Tonarini et al., ${ }^{8}$ Dyar et al. ${ }^{28}$ Leeman et al. ${ }^{29}$ and Gonfiantini et al. ${ }^{17}$ (Fig. 7A).

Tiepolo et al. ${ }^{16}$ used LA MC ICP-MS for boron isotopic analysis of various geological materials. With the exception of tourmaline sample B4, all other materials analysed in their study were in the form of a glass and, similar to this study, the data were corrected using a "standard-sample-standard" bracketing technique, with NIST SRM 610 glass employed as their calibrant. Tiepolo et al. ${ }^{16}$ obtained a mean $\delta^{11} \mathrm{~B}$ value of $-8.24( \pm 0.22 \%, 1 s)$ for the B4 tourmaline which is slightly offset towards a heavier composition relative to our results and the reference value provided by Tonarini et al. ${ }^{8}$ It is possible that this $0.6 \%$ offset could have resulted from the non-matrixmatched calibration strategy used in ref. 8.

\section{B. SIMS matrix effects}

The single collector SIMS boron isotope data for the four tourmaline reference materials that comprise two days of data acquisition are reported in Table 7. The instrument mass discrimination $\left(\Delta_{\text {inst }}\right)$, defined as the ratio between the measured ${ }^{11} \mathrm{~B} /{ }^{10} \mathrm{~B}$ and the reference ${ }^{11} \mathrm{~B} /{ }^{10} \mathrm{~B}$ values, was determined from the mean of $n=29$ analyses of the four tourmaline reference materials. All measured data were corrected by a single $\Delta_{\text {inst }}$ value of $0.98002 \pm 0.00131$ and are reported as $\delta^{11} \mathrm{~B}$ values relative to NIST SRM 951. The overall reproducibility for the $\Delta_{\text {inst }}$ during the analytical session $(1.34 \%, 1 s)$ is typical for this method. It should be noted that the value for the 

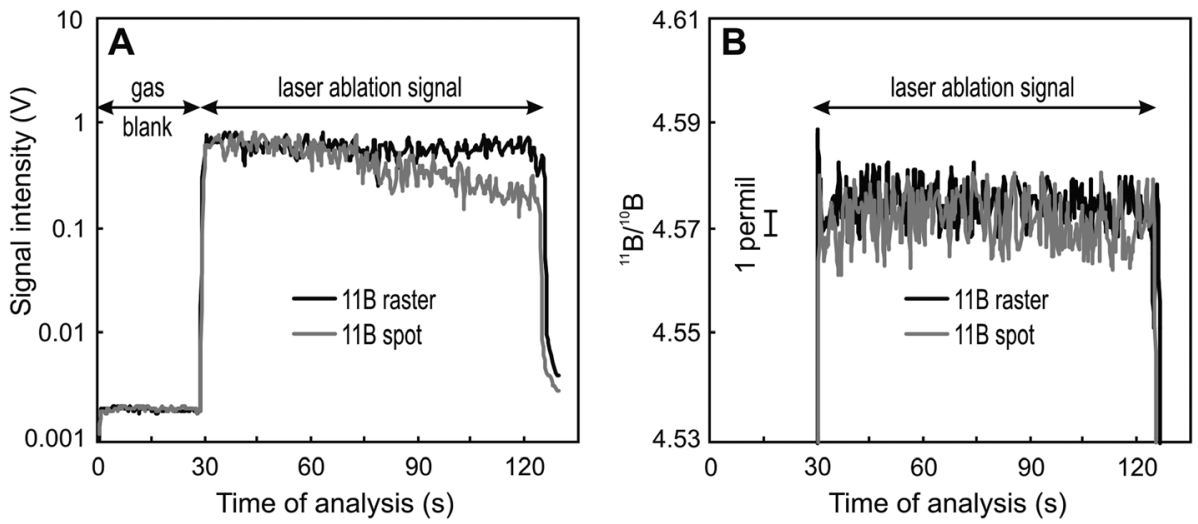

Fig. 4 (A) Laser ablation signal intensity for raster sampling (black line) and spot ablation (grey line). (B) ${ }^{11} \mathrm{~B} /{ }^{10} \mathrm{~B}$ ratio of the measured signals in (A) showing no significant time-dependent isotopic fractionation (change of isotopic ratio during the analysis) for laser raster sampling (black line) and single laser spot ablation (grey line).
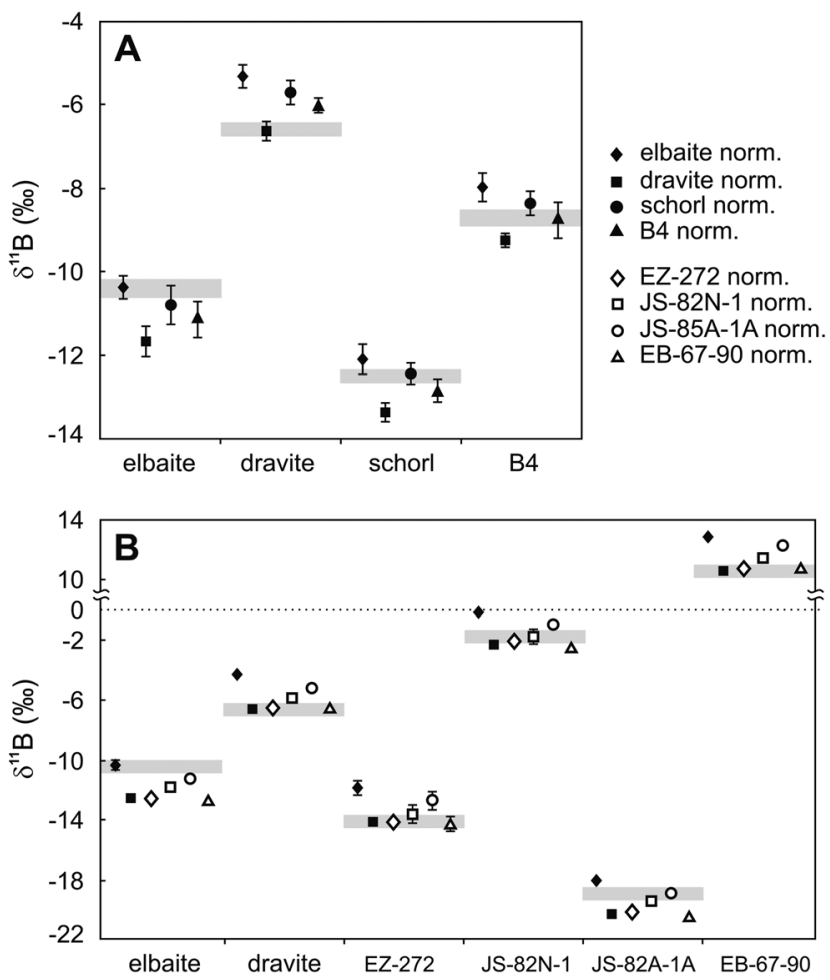

Fig. 5 Variations of $\delta^{11} \mathrm{~B}$ in tourmaline samples for different compositions of the tourmaline standard material in the standard-samplestandard bracketing calibration strategy. Each tourmaline sample was normalised to all tourmaline compositions in the sample mounts S1 (a) and S2 (b) - see the legend. Error bars represent 1s uncertainty of the mean value, TIMS reference values ( \pm 1 s uncertainties) are shown as grey bands and are discussed in the text.

reproducibility of $\Delta_{\text {inst }}$ contains components related both to the reliability of the assigned values for each of the four reference materials as well as any possible sample-specific variations in the isotopic fractionation. This value for the overall reproducibility of $\Delta_{\text {inst }}$ should be taken as the limit to which such a dataset could be interpreted. The repeatabilites of the results for each reference material are in the range of $0.8 \%$ (dravite and schorl) and $1.2 \%$ (elbaite and B4; $c f$. Table 7 ). We note that the $1.3 \%$ standard deviation of B4 tourmaline can be attributed to the last three measurements obtained from this material which show a consistently lighter isotopic composition compared to the rest of the analyses on this sample.

The results obtained by the SIMS technique employing reference values obtained from TIMS measurements (Fig. 7B) suggest that some SIMS data are systematically biased, albeit within their respective analytical uncertainties. Lower $\delta^{11} \mathrm{~B}$ values (with a negative bias of as large as $-1.3 \%$ ) were obtained for elbaite and dravite, while both schorl samples (schorl and B4) were shifted by up to $0.8 \%$ owards higher than expected $\delta^{11} \mathrm{~B}$ values. Here we note a general observation that other boron SIMS isotope studies ${ }^{49}$ have detected a bias of $1 \%$ to at most $2 \%$ o towards lighter isotopic composition for the Li-rich elbaite reference material as compared to the schorl and dravite reference materials. The cause of this bias is difficult to assess without additional analyses of other Li-rich tourmaline reference materials. It is possible that the bias is related to a chemistry-specific matrix effect or to yet unidentified issue related to the reference value of this single tourmaline material. This observed bias in the elbaite results is similar in direction of the isotopic shift but it is substantially less in magnitude compared to the SIMS matrix effect reported in ref. 49 .

\section{Relative merits of laser ablation MC ICP-MS and SIMS}

The main advantages of the LA MC ICP-MS and SIMS techniques over the wet chemical methods are their high spatial resolution and consequently the small sample size required for analysis. The usual amount of sample consumed by SIMS (of the order of few tens to hundreds of pg of total sample mass) is at least four orders of magnitude smaller than for LA MC ICP-MS. Typically, the depth of the SIMS pit produced over 10 minutes of $\mathrm{O}^{-}$ion sputtering in silicate minerals under similar conditions as used in this study varies between 1 and $2 \mu \mathrm{m},{ }^{50}$ corresponding to $c a$. $20-40 \mu \mathrm{m}^{3}$ of tourmaline sample used per analysis. The amount of material removed by laser ablation for each tourmaline analysis by MC ICP-MS (assuming ablation rate of $c a .0 .1 \mu \mathrm{m}$ per laser 

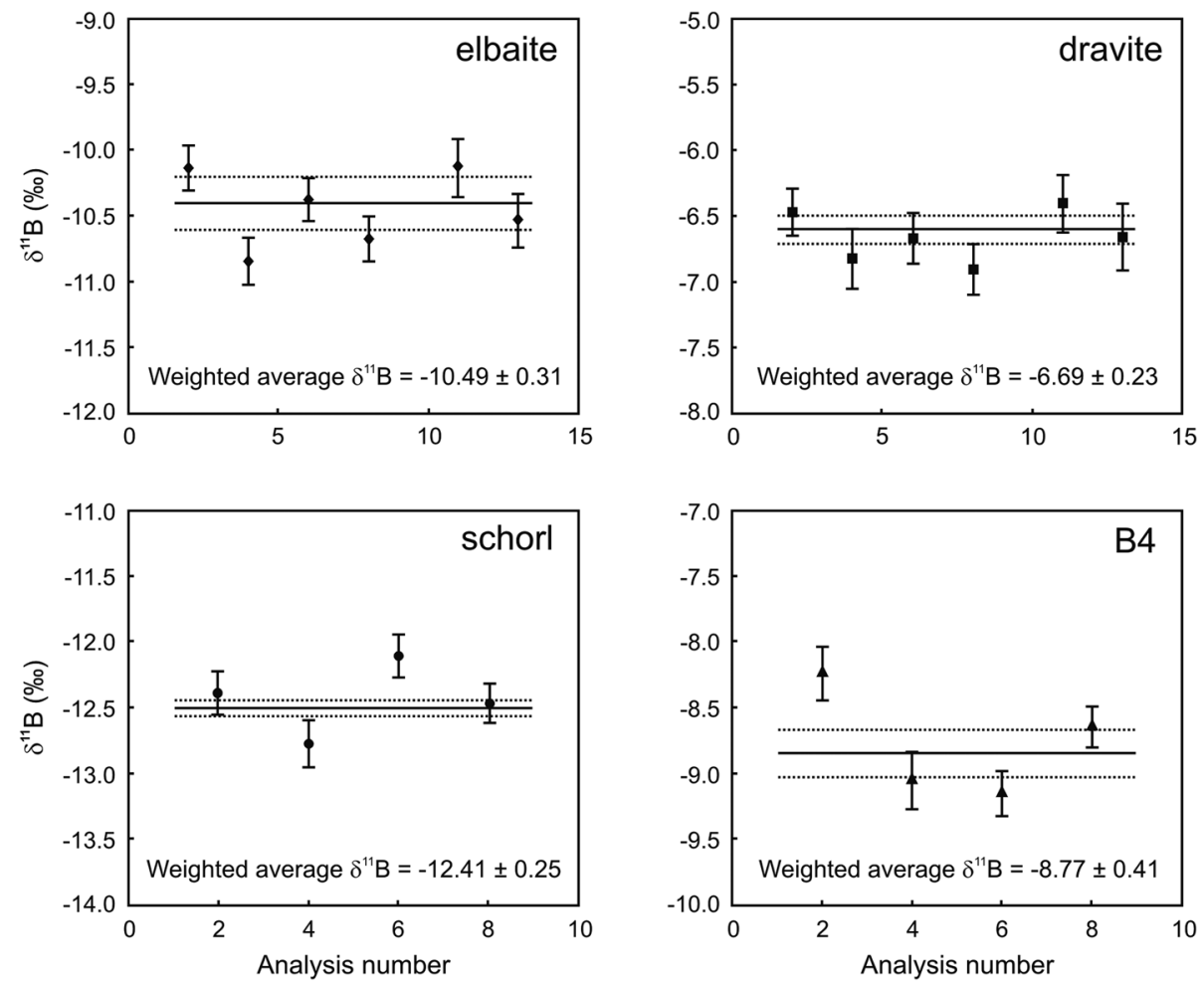

Fig. $6 \delta^{11} \mathrm{~B}$ values for tourmaline reference materials of different compositions. The isotopic composition was calculated by the standardsample-standard bracketing procedure where every second analysis was treated as an unknown. The weighted average $\delta^{11} \mathrm{~B}$ value was calculated for the whole dataset, the uncertainties are 1s. Solid lines represent the mean TIMS reference values previously published for these materials with 1s uncertainty interval shown by the dashed lines.
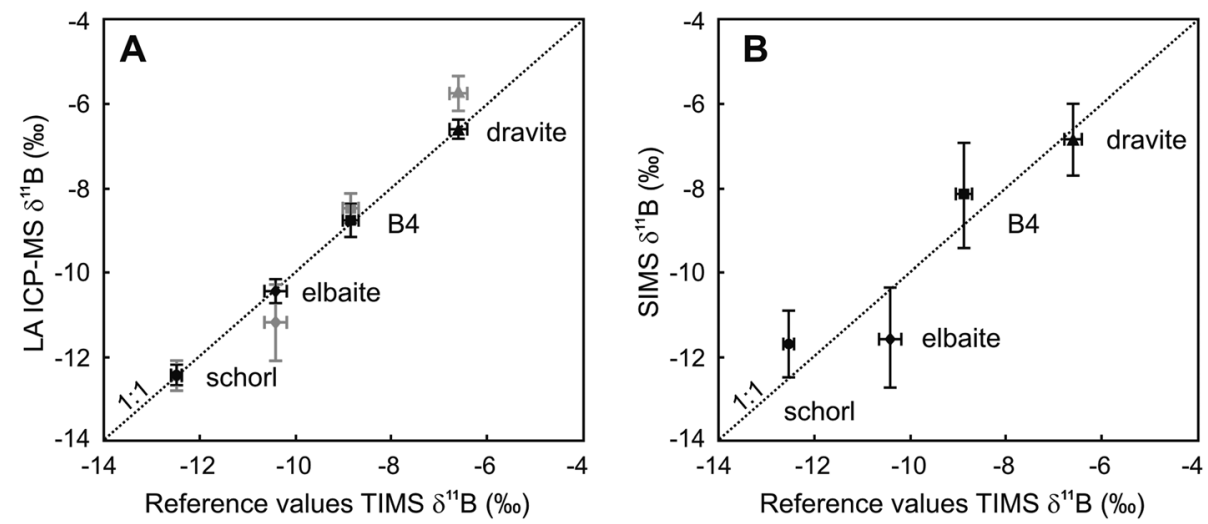

Fig. 7 (A) Comparison of LA MC ICP-MS with TIMS reference values. (i) Data normalized by the standard-sample-standard bracketing procedure with unknown sample and calibration tourmaline material of the same composition (black symbols), (ii) data plotted as grey symbols were normalized using the same approach as for the SIMS data in (B) (see text for details). Error bars represent 1s uncertainty. (B) Comparison of SIMS data with the corresponding TIMS reference values, error bars represent 1 uncertainty.

pulse and $c a .15 \%$ larger ablated volume during laser beam rastering compared to single spot analysis ${ }^{32}$ ) was $c a .2 \times 10^{5} \mu^{3}$. The analyzed mass of the sample during LA MC ICP-MS is, again, some two orders of magnitude smaller as compared to bulk analysis by TIMS. The major advantage of LA MC ICP-MS over single collector SIMS is its speed of the measurement and simple sample handling due to ablation under atmospheric pressure. During this study each LA MC ICP-MS analysis took ca. 2.5 minutes while a total of 11 minutes were needed for a SIMS analysis.

The main goal of this study was to evaluate the matrix effects during the LA MC ICP-MS analyses of $\delta^{11} \mathrm{~B}$ in tourmaline; the single-collector SIMS technique has been well established in the Potsdam laboratory and we did not investigate the influence of individual analytical parameters on the quality of the SIMS data. In order to produce a more direct comparison of LA MC ICP-MS 
and SIMS results, and to eliminate the effect of different data treatment, we have recalculated the measured LA MC ICP-MS data using the same procedure as was used for the SIMS measurements. The results are presented in Fig. 7A (grey symbols) and show a shift of the values due to different data reduction procedures. This shift is likely to result from a matrix effect as the most affected data with the same direction of isotopic shift are from the elbaite and dravite tourmaline samples (Fig. 5). When compared to SIMS (Fig. 7B), the bias between the LA MC ICP-MS results relative to the TIMS reference values (Fig. 7A grey symbols) shows a similar pattern for elbaite, schorl and B4, while dravite shows a bias in the opposite direction. However, all laser ablation and TIMS results have a significant overlap with the $1 s$ uncertainty interval of SIMS results. The results obtained during this study suggest that the overall repeatability obtained by the SIMS-like reduction of the LA MC ICP-MS data is estimated at $0.8 \%(1 s, n=47)$, i.e. somewhat better than that of the SIMS data $(1.3 \%, 1 s, n=29)$. Even with the same data reduction procedures, laser LA MC ICPMS compares favourably with our results from a small geometry single-collector SIMS instrument. The lowest precision obtained by the two analytical techniques was for tourmaline B4, for which a non-homogeneous chemical composition (banding detected by cathodoluminescence imaging) has been reported in the literature. ${ }^{8}$ It should also be noted that the B4 sample was the only multi-grain material used in this study, whereas the other three samples from Dyar et al. ${ }^{28}$ were fragments from single large tourmaline crystals.

Collectively, the LA MC ICP-MS and single collector SIMS can both achieve geologically useful uncertainty for in situ boron isotopic analysis of tourmaline $(0.2-0.5 \%$ and $0.8-1.3 \%, 1 s$, respectively). While the SIMS analysis would be the method of choice for samples that require high spatial resolution, the ca. 4 times faster LA MC ICP-MS would be preferred when large number of analyses and their cost are the main considerations.

\section{Conclusions}

The results of this study suggest that LA MC ICP-MS analysis of boron isotopes in tourmaline is subject to significant matrix effects that can impact the overall data trueness at the $\sim 2.5 \%$ level. The chemical composition of individual tourmaline samples has a systematic effect on the calculated $\delta^{11} \mathrm{~B}$ values depending on the calibration material used for data normalization. With matrix-matched calibration and standard-samplestandard bracketing approach to data reduction, the overall repeatability of LA MC ICP-MS is estimated to be at ca. $0.5 \%(1 s)$ level. The values of $\delta^{11} \mathrm{~B}$ obtained by LA MC ICP-MS are similar to data reported by Tonarini et al. ${ }^{8}$ and Gonfiantini et al. ${ }^{17}$ for the same samples analysed by the P-TIMS technique. Results of this study compare favourably with the overall reproducibility of about $1.3 \%$ o $(1 s)$, which is routinely obtained by the small format SIMS instrument when using a single collector method of data acquisition.

Collectively, the choice of both laser and MC ICP-MS instrument parameters has a significant effect on the measured ${ }^{11} \mathrm{~B} /{ }^{10} \mathrm{~B}$ ratios, in particular as a result of mass discrimination related to variable signal intensities and variable ${ }^{40} \mathrm{Ar}^{4+}$ spectral interference on the ${ }^{10} \mathrm{~B}$ mass peak. This interference can be avoided by optimizing the mass resolution of the instrument (mass resolving power $M / \Delta M$ of $c a .5500$ in this study). Timedependent laser-induced isotopic fractionation of $\mathrm{B}$ was not significant for both the single spot and laser beam raster sampling strategies used during this study. This allows for a choice of optimal ablation mode and pattern that reflects the size, shape and homogeneity of tourmaline samples.

\section{Acknowledgements}

We thank John Slack for providing tourmaline samples for this study and three anonymous reviewers for their constructive and helpful comments on the manuscript.

\section{References}

1 J. Hoefs, Stable Isotope Geochemistry, Springer, Berlin, 6th edn, 2009, ch. 2, pp. 45-47.

2 M. R. Palmer and G. H. Swithart, in Boron: Mineralogy, Petrology and Geochemistry, ed. E. S. Grew and L. M. Anovitz, Reviews in Mineralogy and Geochemistry, 1996, 33, pp. 709-744.

3 W. P. Leeman and V. B. Sisson, in Boron: Mineralogy, Petrology and Geochemistry, ed. E. S. Grew and L. M. Anovitz, Reviews in Mineralogy and Geochemistry, 1996, 33, pp. 645-707.

4 E. J. Catanzaro, C. E. Champion, E. L. Garner, O. Marienko, K. M. Sappenfield and W. R. Shield, US Nat. Bur. Standards, Special Publ., 1970, 260-17, 70.

5 S. Tonarini, M. Pennisi and R. Gonfiantini, Isot. Environ. Health Stud., 2009, 45(2), 169-183.

6 S. K. Sahoo and A. Masuda, Analyst, 1995, 120, 335-339.

7 D. Lemarchand, J. Gailardet, C. Göpel and G. Manhès, Chem. Geol., 2002, 182, 323-334.

8 S. Tonarini, M. Pennisi, A. Adorni-Braccesi, A. Dini, G. Ferrara, R. Gonfiantini, M. Wiedenbeck and M. Gröning, Geostand. Newsl., 2003, 27, 21-39.

9 N. G. Hemming and G. N. Hanson, Chem. Geol., 1994, 114, 147-156.

10 J. J. Shen and C. F. You, Anal. Chem., 2003, 75, 1972-1977. 11 H. I. Gäbler and A. Bahr, Chem. Geol., 1999, 156, 323-330.

12 J. K. Aggarwal, D. Sheppard, K. Mezger and E. Pernicka, Chem. Geol., 2003, 199, 331-342.

13 M. Chaussidon and F. Robert, Earth Planet. Sci. Lett., 1998, 164, 577-589.

14 M. Chaussidon, F. Robert, D. Maning, P. Hanon and E. F. Rose, Geostand. Newsl., 1997, 21, 7-17.

15 P. J. le Roux, S. B. Shirley, L. Benton, E. H. Hauri and T. D. Mock, Chem. Geol., 2004, 203, 123-138.

16 M. Tiepolo, C. Bouman, R. Vannucci and J. Schwieters, Appl. Geochem., 2006, 21, 788-801.

17 R. Gonfiantini, S. Tonarini, M. Gröning, A. Adorni-Braccesi, A. S. Al-Ammar, M. Astner, S. Bächler, R. M. Barnes, R. L. Bassett, A. Cocherie, A. Deyhle, A. Dini, G. Ferrara, J. Gaillardet, J. Grimm, C. Guerrot, U. Krähenbühl, 
G. Layne, D. Lemarchand, A. Meixner, D. J. Northington, M. Pennisi, E. Reitznerova, I. Rodushkin, N. Sogiura, R. Surberg, S. Tonn, M. Wiedenbeck, S. Wunderli, Y. Xiao and T. Zack, Geostand. Newsl., 2003, 27, 41-57.

18 J. K. Aggarwal, F. Böhm, G. Foster, S. Halas, B. Hönisch, S. Y. Jiang, J. Kosler, A. Liba, I. Rodushkin, T. Sheehan, J. J. S. Shen, S. Tonarini, Q. Xi, C. F. You, Z. Q. Zhao and E. Zuleger, J. Anal. At. Spectrom., 2009, 24, 825-831.

19 T. Ishikawa and E. Nakamura, Anal. Chem., 1990, 62(23), 2612-2616.

20 S. Tonarini, M. Pennisi and W. P. Leeman, Chem. Geol., 1997, 142, 129-138.

21 W. P. Leeman, R. D. Vocke, E. S. Beary and P. J. Paulsen, Geochim. Cosmochim. Acta, 1991, 55, 3901-3907.

22 E. Nakamura, T. Ishikawa, J. L. Birck and C. J. Allegre, Chem. Geol., 1992, 94, 193-204.

23 B. L. Jolliff, J. J. Papike and C. K. Shearer, Am. Mineral., 1986, 71, 472-500.

24 D. London, G. B. Morgan and M. B. Wolf, in Boron: Mineralogy, Petrology and Geochemistry, ed. E. S. Grew and L. M. Anovitz, Reviews in Mineralogy and Geochemistry, 1996, 33, pp. 299-330.

25 J. F. Slack, in Boron: Mineralogy, Petrology and Geochemistry, ed. E. S. Grew and L. M. Anovitz, Reviews in Mineralogy and Geochemistry, 1996, 33, pp. 559-644.

26 R. P. Xavier, M. Wiedenbeck, R. B. Trumbull, A. M. Dreher, L. V. S. Monteiro1, D. Rhede, C. E. G. Araújo1 and I. Torresi, Geology, 2008, 36(9), 743-746.

27 R. B. Trumbull, M.-S. Krienitz, G. Grundmann and M. Wiedenbeck, Contrib. Mineral. Petrol., 2009, 157, 411427.

28 M. D. Dyar, M. Wiedenbeck, D. Robertson, L. R. Cross, J. S. Delaney, K. Ferguson, C. A. Francis, E. S. Grew, C. H. Guidotti, R. L. Hervig, J. M. Hughes, J. Husler, W. Leeman, A. V. McGuire, D. Rhede, H. Rothe, R. L. Paul, I. Richards and M. Yates, Geostand. Newsl., 2001, 25(2-3), 441-463.

29 W. P. Leeman and S. Tonarini, Geostand. Newsl., 2001, 25(23), 399-403.

30 M. R. Palmer and J. F. Slack, Contrib. Mineral. Petrol., 1989, 103, 434-451.

31 D. C. Pal, R. B. Trumbull and M. Wiedenbeck, Chem. Geol., 2010, 277, 245-260.
$32 \mathrm{~J}$. Košler, in Laser ablation ICP-MS in the Earth sciences: current practices and outstanding issues, ed. P. Sylvester, Mineral. Assoc. Can. short course series, 2008, vol. 40, pp. 79-93.

33 M. S. A. Horstwood, G. L. Foster, R. R. Parrish, S. R. Noble and G. M. Nowell, J. Anal. At. Spectrom., 2003, 18, 837-846.

34 J. Košler, L. Frost and J. Sláma, in Laser ablation ICP-MS in the Earth sciences: current practices and outstanding issues, ed. P. Sylvester, Mineral. Assoc. Can. short course series, 2008, vol. 40, pp. 315-317.

35 J. Kosler, H. P. Longerich and M. N. Tubrett, Anal. Bioanal. Chem., 2002, 374, 251-254.

36 P. J. Sylvester and M. Ghaderi, Chem. Geol., 1997, 141, 49-65. 37 P. J. Potts, Geostand. Newsl., 1997, 21, 157-161.

38 D. Eshmaeily, R. B. Trumbull, M. Haghnazar, M.-S. Krienitz and M. Wiedenbeck, Eur. J. Mineral., 2009, 21, 347-360.

39 C. G. Galbraith, D. B. Clarke, R. B. Trumbull and M. Wiedenbeck, Econ. Geol., 2009, 104(5), 713-731.

40 M.-S. Krienitz, R. B. Trumbull, A. Hellmann, J. Kolb, F. M. Meyer and M. Wiedenbeck, Miner. Deposita, 2008, 43(4), 421-434.

41 R. B. Trumbull, M.-S. Krienitz, B. Gottesmann and M. Wiedenbeck, Contrib. Mineral. Petrol., 2008, 155, 1-18.

42 B. E. Taylor and J. F. Slack, Econ. Geol., 1984, 79, 17031726.

43 I. Feldmann, W. Tittes, N. Jakubowski, D. Struewer and U. Giessmann, J. Anal. At. Spectrom., 1994, 9, 1007-1014.

44 C. J. Park, Bull. Korean Chem. Soc., 2002, 23(11), 15411544.

45 J. M. Mermet, in Inductively Coupled Plasma Spectrometry and its Applications, ed. S. J. Hill, Blackwell Publishing, Oxford, 2nd edn, 2006, ch. 2, pp. 27-50.

46 H. Andrén, I. Rodushkin, A. Stenberg, D. Malinovsky and D. C. Baxter, J. Anal. At. Spectrom., 2004, 19, 1217-1224.

47 I. Kroslakova and D. Günther, J. Anal. At. Spectrom., 2006, 22, 51-62.

48 W. A. Deer, R. A. Howie and J. Zussman, An Introduction to the Rock-Forming Minerals, Pearson, Harlow, 2nd edn, 1992, p. 130.

49 M. Chaussidon and F. Albarède, Earth Planet. Sci. Lett., 1992, 108, 229-241.

50 A. Müller, R. Thomas, M. Wiedenbeck, R. Seltmann and K. Breiter, Eur. J. Mineral., 2006, 18, 429-440. 